\title{
Synthesis and structural studies of phenyl(iodo) - and methyl(phenyl)palladium(II) complexes of bidentate nitrogen donor ligands
}

\author{
Bertus A. Markies a, Allan J. Canty b, Wim de Graaf a , Jaap Boersma a , Maurits D. Janssen ${ }^{\text {a }}$, \\ Marinus P. Hogerheide ${ }^{a}$, Wilberth J.J. Smeets ${ }^{c}$, Anthony L. Spek ${ }^{c}$ and Gerard van Koten ${ }^{a}$ \\ a Debye Institute, Department of Metal-Mediated Synthesis, Utrecht University, Padualaan 8, 3584 CH Utrecht (Netherlands) \\ ${ }^{b}$ Department of Chemistry, University of Tasmania, GPO Box 252C, Hobart, Tasmania 7001 (Australia) \\ ${ }^{c}$ Bijvoet Center for Biomolecular Research, Laboratory of Crystal and Structural Chemistry, Utrecht University, Padualaan 8, 3584 CH Utrecht \\ (Netherlands)
}

(Received February 7, 1994)

\begin{abstract}
Phenylpalladium(II) complexes of the type PdIPh(N-N), with $\mathrm{N}-\mathrm{N}=N, N, N^{\prime}, N^{\prime}$-tetramethylethylenediamine (tmeda) or $2,2^{\prime}$-bipyridyl (bpy), can be conveniently prepared in $70-95 \%$ yield by oxidative addition of iodobenzene to bis(dibenzylideneacetone)palladium $(0)$ in the presence of the appropriate nitrogen donor ligand. The bromo analogues were obtained in only 5-12\% yield in this way. The complex PdIPh(tmeda) (1a) reacts readily with MeLi to give PdMePh(tmeda) (3) in $88 \%$ yield, whereas PdIPh(bpy) (2a) gives $\mathrm{PdMePh}(\mathrm{bpy})$ (4) and $\mathrm{PdMe}_{2}$ (bpy) in varying ratios. The formation of $\mathrm{PdMe}_{2}$ (bpy) was found to result from the synergistic action of lithium iodide and methyllithium. Pure PdMePh(bpy) (4) was obtained in $82 \%$ yield via ligand-exchange from $\mathrm{PdMePh}(\mathrm{tmeda})(3)$. The crystal structures of $\mathrm{PdIPh}(\mathrm{N}-\mathrm{N})(1 \mathrm{a}, 2 \mathrm{a})$ and $\mathrm{PdMePh}(\mathrm{N}-\mathrm{N})(3,4)$ complexes were determined by $\mathrm{X}$-ray diffraction studies. The results show that the phenyl group is always oriented perpendicular to the coordination plane around palladium, with the largest deviation found for $3\left(14.3(2)^{\circ}\right)$. The Pd-N bond distances in the tmeda complexes $(2.127(6)-2.210(3) \AA)$ are larger than those in the bpy-coordinated complexes $(2.070(8)-2.144(8) \AA$ ). Similarly, the Pd-C(Me) bond distances (2.5703(8) and $2.575(1) \AA$ ) are larger than the $\mathrm{Pd}-\mathrm{C}(\mathrm{Ph})$ bond distances $(1.985(3)-1.996(10) \AA)$.
\end{abstract}

Key words: Palladium; Amine; Oxidative addition; Bipyridine; Crystal structure

\section{Introduction}

New applications of nitrogen donor ligand complexes in organopalladium chemistry are currently being developed; e.g. for organic synthesis involving systems with intramolecular coordination [1], for catalytic coupling reactions of alkyl halides with organotin reagents [2], for modelling of processes that are catalytic for phosphine complexes [3], and for the synthesis of organopalladium(IV) complexes [3a,b;4b-6]. Some of the applications have involved arylpalladium (II) complexes, but these are restricted to complexes in which the aryl group is $\mathrm{C}_{6} \mathrm{~F}_{5}$ or is part of an in-

Correspondence to: Dr. J. Boersma; concerning crystallographic data, Dr. A.L. Spek. tramolecular coordination or a metallacyclic system. Early reports of isolated arylpalladium(II) complexes of nitrogen donor ligands in which the aryl group is not part of a chelating system or of a metallacycle mainly involve pentachlorophenyl and pentafluorophenyl groups [4]. Exceptions are the synthesis of PdIPh(bpy) in $17 \%$ yield from the reaction of iodobenzene with activated palladium powder in the presence of $2,2^{\prime}$-bipyridyl [7], and the formation of $\mathrm{PdCl}(p$-tolyl)(phen) in 93\% yield from the reaction of $\mathrm{Pd}_{2}(\mathrm{dba})_{3} \cdot \mathrm{C}_{6} \mathrm{H}_{6}$ (dba $=$ dibenzylideneacetone) with $p$-tolylmercuric chloride in the presence of 1,10-phenanthroline monohydrate (phen) [8]. Since the start of this work [9] a series of complexes PdClAr(bpy) has been obtained by the direct activation of toluene, xylenes and mesitylenes [10]; they werc obtained in low yicld (3-16\%), except for $\mathrm{PdCl}\left(2,5-\mathrm{Me}_{2} \mathrm{C}_{6} \mathrm{H}_{3}\right)($ bpy) (64\%) and $\mathrm{PdClPh}($ bpy) (74\%). 
Aryl halides readily undergo oxidative addition reactions with palladium $(0)$ phosphine complexes [11], and it has recently been demonstrated that alkyl and aryl halides undergo similar reactions with $\mathrm{Pd}(\mathrm{dba})_{2}$ or $\mathrm{Pd}_{2}(\mathrm{dba})_{3} \cdot \mathrm{CHCl}_{3}$ in the presence of nitrogen donor groups to form palladium(II) nitrogen donor complexes [6c;9;12-15]. For example, the reaction of iodomethane with $\mathrm{Pd}(\mathrm{dba})_{2}$ in the presence of bpy gives PdIMe(bpy) in $79 \%$ yield [13]. In view of the established role of bpy and related diimines in catalysis [2;16], together with the application of bpy and $N, N, N^{\prime}, N^{\prime}$-tetramethylethylenediamine (tmeda) in the development of organopalladium(II) $[4-7 ; 9 ; 10 ; 13 ; 17]$ and palladium(IV) chemistry [4b-6], we decided to study the reactions of aryl halides with $\operatorname{Pd}(\mathrm{dba})_{2}$ in the presence of these representative aromatic and aliphatic nitrogen donor bidentate ligands $\left(\mathrm{L}_{2}\right)$. High yield routes to simple arylpalladium(II) complexes, and synthesis of the first alkyl(aryl)palladium(II) complexes of nitrogen donor ligands are described, together with structural studies of $\operatorname{PdIPh}\left(\mathrm{L}_{2}\right)$ and $\operatorname{PdMePh}\left(\mathrm{L}_{2}\right)$.

\section{Results}

\subsection{Synthesis}

The oxidative addition of iodobenzene to $\mathrm{Pd}(\mathrm{dba})_{2}$ in the presence of tmeda (eqn. 1, Table 1) proceeds very smoothly at $50^{\circ} \mathrm{C}$ in benzene to give orange PdIPh(tmeda) (1a) in ca. 95\% yield, a higher yield than that initially reported (75\% [9a]) for the synthesis in THF. The analogous reaction with bromobenzene (Table 1) gave only $8 \%$ of the desired complex $\mathrm{PdBrPh}$ (tmeda) (1b) in benzene, but a slightly higher yield $(12 \%)$ was obtained in THF. The formation of large quantities of palladium metal at the higher temperature $\left(80^{\circ} \mathrm{C}\right)$ needed in both solvents for bromobenzene addition indicates that thermal decomposition of $\mathrm{Pd}(\mathrm{dba})_{2}$ is faster under these conditions than oxidative addition to give $\mathbf{1 b}$. The complexes PdIPh(bpy) (2a) and $\mathrm{PdBrPh}(\mathrm{bpy})$ (2b) were obtained in $70 \%$ and

TABLE 1. Halide and solvent dependence of the oxidative addition of phenyl halides

\begin{tabular}{llllll}
\hline Complex & $\mathrm{PhX}$ & $\mathrm{N}-\mathrm{N}$ & $\mathrm{T}\left({ }^{\circ} \mathrm{C}\right)$ & Solvent & Yield (\%) \\
\hline 1a & $\mathrm{PhI}$ & tmeda & 50 & benzene & 95 \\
& $\mathrm{PhI}$ & tmeda & 50 & THF & 75 \\
2a & $\mathrm{PhI}$ & bpy & 50 & benzene & 70 \\
1b & $\mathrm{PhBr}$ & tmeda & 80 & benzene & 8 \\
& $\mathrm{PhBr}$ & tmeda & 80 & THF & 12 \\
2b & $\mathrm{PhBr}$ & bpy & 80 & benzene & 5 \\
\hline
\end{tabular}

$5 \%$ yields, respectively, by a similar procedure. The complexes $\mathbf{1 a , b}$ and $\mathbf{2 \mathbf { a } , \mathbf { b }}$ are readily purified by recrystallization from $\mathrm{CH}_{2} \mathrm{Cl}_{2} / \mathrm{Et}_{2} \mathrm{O}$ at $-20^{\circ} \mathrm{C}$. Crystals suitable for X-ray structural analysis (vide infra) of $\mathbf{2 a}$ were obtained by this method, while 1a was best recrystallized from hot benzene.

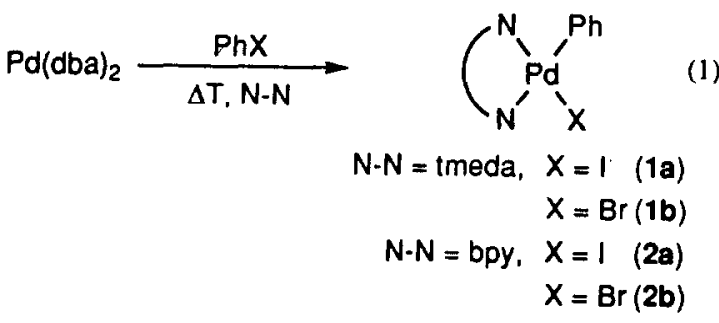

Resonances for bpy-H6 protons adjacent to the halogen atom in PdXMe(bpy) occur downfield from bpy-H6 protons adjacent to the methyl group, by 0.69 $\mathrm{ppm}(\mathrm{X}=\mathrm{Br})$ and $0.83 \mathrm{ppm}(\mathrm{X}=\mathrm{I})$ [13]. Similar effects occur for PdXPh(bpy), but the differences are greater [1.53 ppm $(\mathrm{X}=\mathrm{Br}), 1.96 \mathrm{ppm}(\mathrm{X}=\mathrm{I})]$. This effect is assumed to be due to orientation of the phenyl group approximately normal to the coordination plane (vide infra), resulting in an upfield shift for the high-field bpy-H6 protons. The chemical shifts of the phenyl protons do not depend strongly on the halide, in contrast to those for the cyclometallated complexes $\operatorname{PdX}(\mathrm{CNN})(\mathrm{I}, \mathrm{X}=\mathrm{Cl}, \mathrm{Br}, \mathrm{I}$ and $\mathrm{CNN}=\mathrm{N}$-(2-benzyl)$N, N^{\prime}, N^{\prime}$-trimethylethylenediamine), where the phenyl group lies in the coordination plane and thus the ortho proton is closer to the halogen atom [6c].

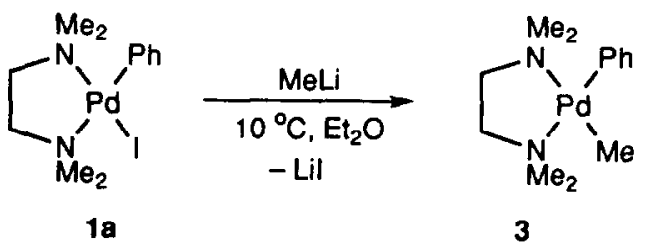

Dimethylpalladium(II) complexes containing nitrogen donor ligands have been obtained either by methylation of the corresponding dihalide complexes using methylmetal reagents $[6 a ; 13 ; 17 a]$, or by ligand-exchange reactions [6a;13]. Reaction of $1 \mathrm{a}$ with methyllithium (eqn. 2) in diethyl ether gave beige PdMePh(tmeda) (3) in $88 \%$ yield. In the synthesis of the bpy analogue, PdMePh(bpy) (4), by this route both 4 and the dimethyl complex, $\mathrm{PdMe}_{2}$ (bpy) were formed in varying ratios. Bright yellow 4 was however readily obtained in $82 \%$ yield from 3 by exchange of tmeda for bpy (eqn. 3). 
<smiles>CN1CCN[PH]1(c1ccccc1)[N+](C)(C)C</smiles>

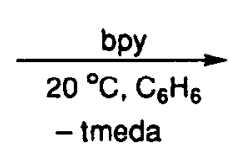

3<smiles>[Y][Pb]1([X])c2ccccc2CN1CC</smiles>

The formation of $\mathrm{PdMe}_{2}$ (bpy) in the reaction of PdIPh(bpy) with MeLi indicates that cleavage of the $\mathrm{Pd}-\mathrm{Ph}$ bond occurs during the reaction. Formation of a palladate intermediate [18a], i.e. $\mathrm{Li}\left[\mathrm{PdMe}{ }_{2} \mathrm{Ph}(\mathrm{bpy})\right]$, which would allow the loss of a phenyl group as $\mathrm{PhLi}$ does not appear to occur, since the reaction of PdMePh(bpy) with MeLi does not generate $\mathrm{PdMe}_{2}$ (bpy). Further investigations showed that addition of lithium iodide to 4 caused rapid decomposition to palladium(0) and several organic products. However, substantial amounts of $\mathrm{PdMe}_{2}$ (bpy) were obtained when lithium iodide and methyl lithium were simultaneously added to $\mathrm{PdMePh}(\mathrm{bpy})$ (4). The formation of the dimethyl complex must therefore be due to the synergistic action of methyllithium and lithium iodide. Further investigations of the mechanism of both the lithium iodide induced decomposition and the exchange reaction are in progress. Complexes 3 and 4 can be handled readily in air and are thermally stable at room temperature for at least a few hours, although longer storage requires temperatures of $-20^{\circ} \mathrm{C}$ or lower. Analytically pure samples and crystals suitable for $\mathrm{X}$-ray structural

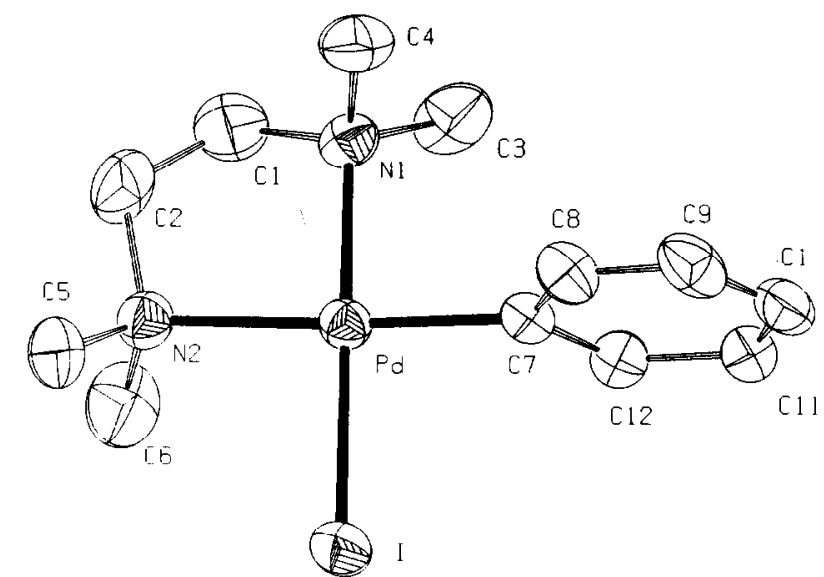

Fig. 1. ORTFP drawing ( $30 \%$ probability level) of PdIPh(tmeda) (1a).

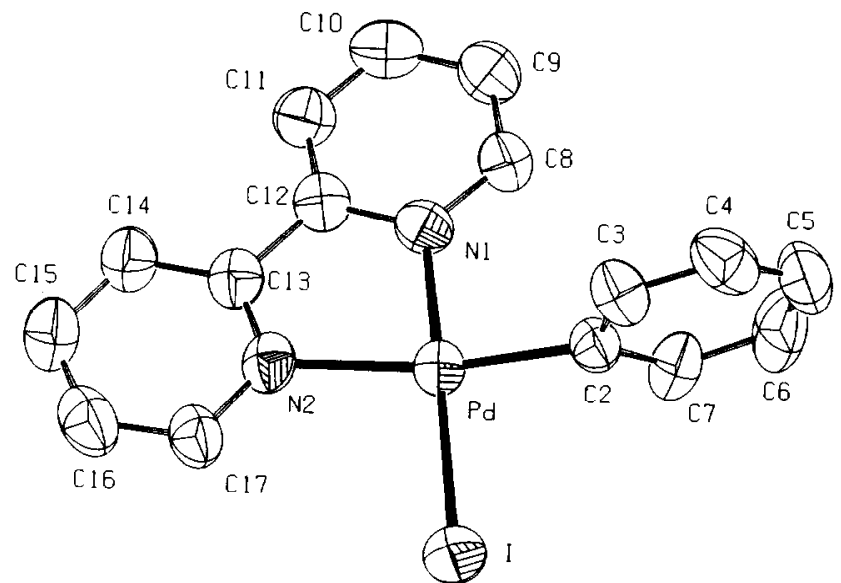

Fig. 2. ORTEP drawing (50\% probability level) of PdIPh(bpy) (2a).

analysis (vide infra) were obtained from acetone/ pentane at $-20^{\circ} \mathrm{C}$.

2.2. Structures of the $P d X P h\left(L_{2}\right)$ and $P d M e P h\left(L_{2}\right)$ complexes in the solid state

In order to determine the structural parameters of these new types of complexes, and to assess the influence of the presence of the phenyl ring on the structure compared to analogous methyl- and dimethyl complexes, the crystal structures of the complexes $1 \mathbf{a}, 2 \mathbf{a}, 3$ and 4 were determined. ORTEP representations of these structures are presented in Figs. 1-4, and selected bond distances and angles are given in Table 2. The phenyl ring is, in all cases, approximately perpendicular to the coordination plane, with the largest deviation (14.3(2) $)^{\circ}$ shown by PdMePh(tmeda) (3). The Pd-N distances in both the tmeda and the bpy complexes are well within the range $(2.03-2.20 \AA)$ reported for the closely related organopalladium(II) complexes $\mathrm{PdMe}_{2}$ (tmeda) [6a], [PdMe(bpy) $\left(\gamma\right.$-picoline)]BF ${ }_{4}$ [17p] and $\mathrm{Pd}\left(\mathrm{N}_{3}\right)\left(\mathrm{CH}_{2} \mathrm{Ph}\right)($ bpy) [5e].

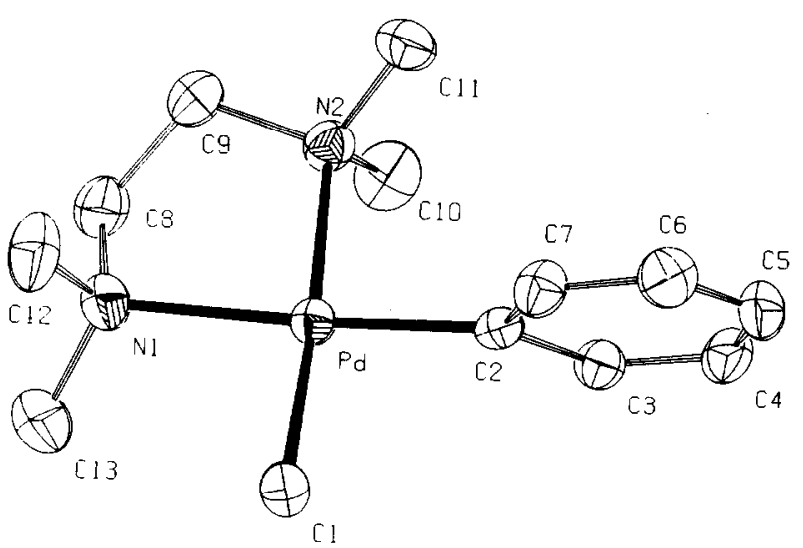

Fig. 3. ORTEP drawing (30\% probability level) of PdMePh(tmeda) (3) 


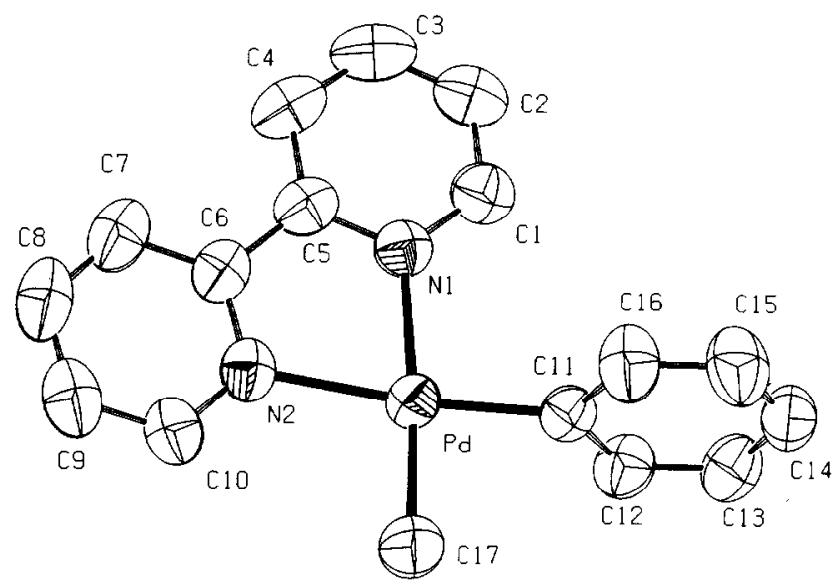

Fig. 4. ORTEP drawing (50\% probability level) of PdMePh(bpy) (4).

The $\mathrm{Pd}-\mathrm{Me}$ bond distance in $\mathrm{PdMePh}$ (bpy) (4, $2.020(5) \AA)$ is normal for a methyl group trans to a pyridine nitrogen, as illustrated by the value for the related complex [PdMe(bpy)( $\gamma$-picoline)]BF B $_{4}(2.036(6)$ $\AA$ ). The Pd-Me bond distance in PdMePh(tmeda) (3, $2.107(3) \AA$ ) is ca. $0.08 \AA$ longer than that in $\mathrm{PdMe}_{2}$ (tmeda) (2.026(3) $\AA$ ) [6a], although the Pd$\mathrm{N}($ trans to $\mathrm{Me})$ bond distance $(2.210(3) \AA)$ and N-Pd$\mathrm{N}\left(82.5(1)^{\circ}\right)$ and $\mathrm{C}-\mathrm{Pd}-\mathrm{C}\left(88.3(1)^{\circ}\right)$ bond angles of 3 are comparable to those in $\mathrm{PdMe}_{2}$ (tmeda) (2.200(2) $\AA$, $82.7(8)^{\circ}$ and $87.4(1)^{\circ}$, respectively). The $\mathrm{Pd}-\mathrm{C}$ (phenyl) bonds in 3 and 4 are significantly shorter than the $\mathrm{Pd}-\mathrm{C}$ (methyl) bonds, although this effect is more pro-

TABLE 2. Selected bond distances $(\AA)$ and bond angles $\left(^{\circ}\right)$

\begin{tabular}{|c|c|c|c|c|}
\hline & \multicolumn{4}{|l|}{ Complexes } \\
\hline & $\overline{1 a}$ & $2 a$ & 3 & 4 \\
\hline \multicolumn{5}{|l|}{ Bond distances } \\
\hline $\mathrm{Pd}-\mathrm{N}(\mathrm{a})^{\mathbf{a}}$ & $2.127(6)$ & $2.070(8)$ & $2.210(3)$ & $2.117(3)$ \\
\hline $\mathrm{Pd}-\mathrm{N}(\mathrm{b})^{\mathrm{a}}$ & $2.193(6)$ & $2.144(8)$ & $2.195(3)$ & $2.138(3)$ \\
\hline $\mathrm{Pd}-\mathrm{C}(\mathrm{Ph})$ & $1.992(7)$ & $1.996(10)$ & $1.985(3)$ & $1.985(3)$ \\
\hline $\mathrm{Pd}-\mathrm{C}(\mathrm{Me})$ & & & $2.107(3)$ & $2.020(5)$ \\
\hline Pd-I & $2.5703(8)$ & $2.575(1)$ & & \\
\hline \multicolumn{5}{|l|}{ Bond angles } \\
\hline $\mathrm{N}(\mathrm{a})-\mathrm{Pd}-\mathrm{N}(\mathrm{b})$ & $84.0(2)$ & $78.2(3)$ & $82.5(1)$ & $77.2(1)$ \\
\hline $\mathrm{N}(\mathrm{a})-\mathrm{Pd}-\mathrm{C}(\mathrm{Ph})$ & $92.8(3)$ & 93.5(4) & $95.5(1)$ & 98.3(1) \\
\hline$N(b)-P d-C(M e)$ & & & $93.8(1)$ & $99.0(2)$ \\
\hline$N(b)-P d-I$ & $95.8(2)$ & $100.1(2)$ & & \\
\hline $\mathrm{C}(\mathrm{Ph})-\mathrm{Pd}-\mathrm{C}(\mathrm{Me})$ & & & $88.3(1)$ & $85.7(2)$ \\
\hline$C(P h)-P d-I$ & $87.4(2)$ & $88.7(3)$ & & \\
\hline $\mathrm{N}(\mathrm{a})-\mathrm{Pd}-\mathrm{C}(\mathrm{Me})$ & & & $176.3(1)$ & $175.5(2)$ \\
\hline$N(a)-P d-I$ & $178.3(1)$ & $173.9(3)$ & & \\
\hline $\mathrm{N}(\mathrm{b})-\mathrm{Pd}-\mathrm{C}(\mathrm{Ph})$ & $176.8(3)$ & $170.1(4)$ & $176.4(1)$ & $173.4(1)$ \\
\hline$\theta^{\mathrm{b}}$ & $87.5(3)$ & $88.7(5)$ & $75.7(2)$ & $78.7(2)$ \\
\hline
\end{tabular}

a $\mathrm{N}(\mathrm{a})$ : trans to I or $\mathrm{Me}$; $\mathrm{N}(\mathrm{b})$ : trans to $\mathrm{Ph} .{ }^{\mathrm{b}}$ Calculated angle between the plane of the phenyl ring and the coordination plane defined by $\mathrm{N} 1, \mathrm{~N} 2, \mathrm{C} 1, \mathrm{C} 2$ or $\mathrm{N} 1, \mathrm{~N} 2, \mathrm{C} 1, \mathrm{I}$. nounced for the tmeda coordinated complex (3). This is consistent with the general trend that $\mathrm{Pd}-\mathrm{C}\left(\mathrm{sp}^{2}\right)$ bond distances (1.89-2.00 $\AA$ [19]) are shorter than Pd-C(sp $\left.{ }^{3}\right)\left(2.08-2.13 \AA\right.$ [20]). Similarly, the Pd-N(sp $\left.{ }^{2}\right)$ bond distances $(2.070(8)-2.144(8) \AA)$ in the bpy complexes are shorter than the $\mathrm{Pd}-\mathrm{N}\left(\mathrm{sp}^{3}\right)$ bond distances in the tmeda complexes $(2.127(6)-2.210(3) \AA)$. Surprisingly, the Pd-I bond lengths in PdIPh(tmeda) (1a) and PdIPh(bpy) (2a) are similar, while the Pd-Me bond lengths in the analogous $\mathrm{PdMcPh}(\mathrm{N}-\mathrm{N})$ complexes (3, 4) differ by $c a$. $0.08 \AA$. The Pd-I bonds of 1a and $2 \mathrm{a}$ are $c a$. $0.3 \AA$ shorter than those in the palladium(IV) complex $\mathrm{PdIMe}_{3}$ (bpy) [5b]. This is probably a result of the stronger trans influence of the methyl group in $\mathrm{PdIMe}_{3}$ (bpy) compared with that of the nitrogen donors in $\mathbf{1 a}$ and $\mathbf{2 a}$.

\section{Discussion}

Recently there has been significant progress in the development of suitable reagents for the synthesis of methyl(halogeno)- and dimethyl-palladium(II) complexes with nitrogen, phosphorus or mixed nitrogen/ phosphorus donor ligands; in particular the applications of PdIMe(tmeda) [21], PdClMe(cod) [22], $\left[\mathrm{PdMe}\left(\mathrm{SMe}_{2}\right) \mathrm{X}\right]_{2} \quad(\mathrm{X}=\mathrm{Cl}, \mathrm{Br}, \quad \mathrm{I}) \quad[13 ; 17 \mathrm{p} ; 23 ; 24]$, [PdMe ${ }_{2}$ (pyridazine) $]_{n}[13 ; 23 \mathrm{~b}]$ and $\mathrm{PdMe}_{2}$ (tmeda) [6a] have been explored. These reactions all proceed under ambient conditions in common organic solvents in moderatc to high yield. The facile oxidative addition of iodobenzene to $\mathrm{Pd}(\mathrm{dba})_{2}$ in the presence of bidentate nitrogen donor ligands now allows the synthesis of $\operatorname{PdIPh}\left(\mathrm{L}_{2}\right)$ complexes $\left(\mathrm{L}_{2}=\right.$ tmeda or bpy $)$ in high yield. These complexes are thermally very stable, like their methyl analogues. The complex PdIPh(tmeda) (1a) has also been shown to be a very good reagent for the synthesis of other $\operatorname{PdIPh}\left(\mathrm{L}_{2}\right)$ complexes, e.g. $\mathrm{L}_{2}=$ $(R, R)$-diop $(75 \%)$ or $2 \mathrm{PPh}_{3}(90 \%)$ [9a]. The yields of the bromo complexes, i.e. 8-12\% (1b) and 5\% (2b), are very low compared with those from oxidative addition of aryl bromides that contain potentially intramolecular coordinating substituents; e.g., 1-bromo-2,6-bis[(dimethylamino)methyl]benzene (NCN-Br) reacts with $\mathrm{Pd}(\mathrm{dba})_{2}$ to give $\mathrm{PdBr}(\mathrm{NCN})$ in $88 \%$ yield [15]. Whether this is due to the aryl moiety being kept near the palladium centre or to the fact that the substituent lowers the oxidation potential of the metal is not known.

Complexes of the type M(alkyl)(aryl)(N-N) do not appcar to have been reported for the other nickel triad elements. The availability of $\mathrm{PdMePh}(\mathrm{tmeda})$ as a suitable substrate for the synthesis of related complexes enables the development of new organopalladium(II) and -(IV) chemistry; e.g. comparisons of the reactivity 
of Pd-alkyl and Pd-aryl bonds. In a separate study we have reported on the oxidative addition of alkyl halides to $\mathrm{PdMePh}(\mathrm{N}-\mathrm{N})(\mathrm{N}-\mathrm{N}=$ tmeda, bpy) to give the first examples of mono-arylpalladium(IV) compounds [25]. Finally it must be noted that the molecular structures of the complexes PdIPh(N-N) $(1 a, 2 a)$ and $\mathrm{PdMePh}(\mathrm{N}-$ $\mathrm{N})(3,4)$ in the solid state now provide important structural data for arylpalladium complexes in which the aryl group is not part of a metallacycle or a cyclometallation system. The availability of these structural details is of great importance for numerical studies.

\section{Experimental section}

All operations were conducted under dry nitrogen by use of Schlenk techniques. Benzene, pentane and diethyl ether were all freshly distilled from sodium/ benzophenone ketyl. Methyllithium (1.6 $\mathrm{M}$ in diethyl ether), $N, N, N^{\prime}, N^{\prime}$-tetramethylethylenediamine (tmeda), $2,2^{\prime}$-bipyridine (bpy), iodobenzene, bromobenzene and acetone (p.a.) were obtained from Janssen Chimica and used without purification. Bis(dibenzylideneacetone) palladium( 0 ) was prepared by a published procedure [26]. ${ }^{1} \mathrm{H}$ NMR spectra were recorded on a Bruker AC300 (300 MHz) spectrometer. Chemical shifts are given in ppm relative to tetramethylsilane. Microanalyses were performed by the Institute for Applied Chemistry (TNO), Zeist, Netherlands.

\subsection{Preparation of PdIPh(tmeda) (1a)}

To a purple solution of $4.0 \mathrm{~g}(7 \mathrm{mmol})$ of $\mathrm{Pd}(\mathrm{dba})_{2}$ in $100 \mathrm{ml}$ of benzene were added $1.3 \mathrm{ml}(9 \mathrm{mmol})$ of tmeda and $1.1 \mathrm{ml}(10 \mathrm{mmol})$ of iodobenzene. The mixture was slowly heated to $50^{\circ} \mathrm{C}$ during which the colour changed to green. After filtration of the solution through filter-aid the volatiles were evaporated and the residue washed with diethyl ether $(4 \times 50 \mathrm{ml})$. Yield: $2.8 \mathrm{~g}(95 \%)$. Recrystallization was from boiling benzene or methylene chloride/diethyl ether. Anal. Found: C, 43.2; $\mathrm{H}, 4.8 ; \mathrm{N}, 6.1 . \mathrm{C}_{12} \mathrm{H}_{21} \mathrm{IN}_{2} \mathrm{Pd}$ calcd. $\mathrm{C}, 33.8 ; \mathrm{H}$, $5.0 ; \mathrm{N}, 6.6 \% .{ }^{1} \mathrm{H}$ NMR $\left(\mathrm{CDCl}_{3}\right) \delta: 2.26\left(6 \mathrm{H}, \mathrm{s}, \mathrm{NMe}_{2}\right)$, $2.58\left(4 \mathrm{H}, \mathrm{AA}^{\prime} \mathrm{BB}^{\prime}, 2 \mathrm{CH}_{2}\right), 2.62\left(6 \mathrm{H}, \mathrm{s}, \mathrm{NMe}_{2}\right), 6.75$ $\left(1 \mathrm{H}, \mathrm{t}, 2 \times{ }^{3} J=7.1 \mathrm{~Hz}, p-\mathrm{Ph}\right), 6.88\left(2 \mathrm{H}, \mathrm{dd},{ }^{3} J=7.1\right.$ and $7.7 \mathrm{~Hz}, m-\mathrm{Ph}), 7.20\left(2 \mathrm{H}, \mathrm{d},{ }^{3} J=7.7 \mathrm{~Hz}, o-\mathrm{Ph}\right)$. Complexes $1 \mathbf{b}, \mathbf{2 a}$ and $\mathbf{2 b}$ were prepared similarly.

\section{2. $P d B r P h(t m e d a)(1 b)$}

Yield: $8 \%\left(\mathrm{C}_{6} \mathrm{H}_{6}\right)$ or $12 \%$ (THF). Anal. Found: C, 37.5; $\mathrm{H}, 5.45 ; \mathrm{N}$, 7.3. $\mathrm{C}_{12} \mathrm{H}_{21} \mathrm{BrN}_{2} \mathrm{Pd}$ calcd. C, 34.0; $\mathrm{H}$, 5.6; N, 7.4\%. ${ }^{1} \mathrm{H}$ NMR $\left(\mathrm{CDCl}_{3}\right) \delta: 2.39\left(6 \mathrm{H}, \mathrm{s}, \mathrm{NMe}_{2}\right)$, $2.62\left(6 \mathrm{H}, \mathrm{s}, \mathrm{NMe}_{2}\right), 2.63\left(4 \mathrm{H}, \mathrm{AA}^{\prime} \mathrm{BB}^{\prime}, 2 \mathrm{CH}_{2}\right), 6.82$ $\left(1 \mathrm{H}, \mathrm{t}, 2 \times{ }^{3} J=7.2 \mathrm{~Hz}, p-\mathrm{Ph}\right), 6.92\left(2 \mathrm{H}, \mathrm{dd},{ }^{3} J=7.2\right.$ and $7.3 \mathrm{~Hz}, m-\mathrm{Ph}), 7.25\left(2 \mathrm{H}, \mathrm{d},{ }^{3} J=7.3 \mathrm{~Hz}, o-\mathrm{Ph}\right)$.

\section{3. $P d I P h$ (bpy) (2a)}

Yield: 70\%. Anal. Found: C: C, 40.5; H, 2.85; N, 5.8. $\mathrm{C}_{15} \mathrm{H}_{13} \mathrm{IN}_{2} \mathrm{Pd}$ calcd. C, 41.2; $\mathrm{H}, 2.8 ; \mathrm{N}, 6.0 \% .{ }^{1} \mathrm{H}$ NMR $\left(\mathrm{CDCl}_{3}\right) \delta: 6.94\left(1 \mathrm{H}, \mathrm{t}, 2 \times{ }^{3} J=7.2 \mathrm{~Hz}, p-\mathrm{Ph}\right), 7.06$ $\left(2 \mathrm{H}, \mathrm{dd},{ }^{3} J=6.9\right.$ and $\left.7.2 \mathrm{~Hz}, m-\mathrm{Ph}\right), 7.35(1 \mathrm{H}, \mathrm{m}$, $\mathrm{H}_{5^{\prime}}$-bpy), $7.40\left(2 \mathrm{H}, \mathrm{d},{ }^{3} \mathrm{~J}=6.9 \mathrm{~Hz}, o-\mathrm{Ph}\right), 7.54(1 \mathrm{H}, \mathrm{m}$, $\mathrm{H}_{5}$-bpy), $7.69\left(1 \mathrm{H}, \mathrm{d},{ }^{3} J=3.9 \mathrm{~Hz}, \mathrm{H}_{6^{\prime}}\right.$-bpy), $8.00(2 \mathrm{H}$, $\mathrm{m}, \mathrm{H}_{4,4^{\prime}}$-bpy), $8.09\left(2 \mathrm{H}, \mathrm{m}, \mathrm{H}_{3,3^{\prime}}\right.$-bpy), $9.65(1 \mathrm{H}, \mathrm{d}$, ${ }^{3} J=5.2 \mathrm{~Hz}, \mathrm{H}_{6}-$ bpy).

\section{4. $P d B r P h(b p y)(2 b)$}

Yield: 5\%. Anal. Found: C, 45.3; H, 3.2; N, 6.6. $\mathrm{C}_{15} \mathrm{H}_{13} \mathrm{BrN}_{2} \mathrm{Pd}$ calcd. C, 45.8; $\mathrm{H}, 3.1 ; \mathrm{N}, 6.7 \%$. ${ }^{1} \mathrm{H}$ NMR $\left(\mathrm{CDCl}_{3}\right) \delta: 6.97\left(1 \mathrm{H}, \mathrm{t}, 2 \times{ }^{3} J=7.2 \mathrm{~Hz}, p-\mathrm{Ph}\right)$, $7.07\left(2 \mathrm{H}, \mathrm{dd},{ }^{3} J=7.2\right.$ and $\left.7.9 \mathrm{~Hz}, m-\mathrm{Ph}\right), 7.33(1 \mathrm{H}, \mathrm{m}$, $\mathrm{H}_{5^{\prime}}$ bpy), $7.42\left(2 \mathrm{H}, \mathrm{d},{ }^{3} \mathrm{~J}=7.9 \mathrm{~Hz}, o-\mathrm{Ph}\right), 7.56(1 \mathrm{H}, \mathrm{m}$, $\mathrm{H}_{5}$-bpy), $7.91\left(1 \mathrm{H}, \mathrm{d}^{3} \mathrm{~J}=4.5 \mathrm{~Hz}, \mathrm{H}_{6^{\prime}}\right.$-bpy), $8.10(4 \mathrm{H}, \mathrm{m}$, $\mathrm{H}_{3,3^{\prime}}$ and $\mathrm{H}_{4,4^{-}}$-bpy), $9.44\left(1 \mathrm{H}, \mathrm{d},{ }^{3} \mathrm{~J}=5.1 \mathrm{~Hz}, \mathrm{H}_{6}\right.$-bpy).

\subsection{Preparation of PdMePh(tmeda) (3)}

A suspension of $1 \mathrm{a}(2.39 \mathrm{~g}, 5.6 \mathrm{mmol})$ in $100 \mathrm{ml}$ of diethyl ether was cooled to $-40^{\circ} \mathrm{C}$ and treated with 3.8 $\mathrm{ml}$ of MeLi (1.6 M in diethyl ether). The mixture was allowed to warm up slowly, and the solution became clear at $c a .+10^{\circ} \mathrm{C}$. The solution was then cooled to $0^{\circ} \mathrm{C}$ and treated with water $(10 \mathrm{ml})$. The mixture was cooled to $-40^{\circ} \mathrm{C}$ and the ether layer decanted from the frozen aqueous layer. Subsequently, the volatiles were evaporated in vacuo, after which the greyish residue was dissolved in $10 \mathrm{ml}$ of benzene and the solution filtered through filter-aid. Evaporation of the solvent gave a beige solid, from which traces of benzene were removed by washing with pentane $(4 \times 20$ $\mathrm{ml}$ ). Yield: $\mathbf{8 8 \%}$. Crystals suitable for the X-ray structure determination were obtained from acetone/ pentane at $-20^{\circ} \mathrm{C}$. Anal. Found: $\mathrm{C}, 49.3 ; \mathrm{H}, 7.4 ; \mathrm{N}$, 8.9. $\mathrm{C}_{13} \mathrm{H}_{24} \mathrm{~N}_{2} \mathrm{Pd}$ calcd. C, 49.6; $\mathrm{H}, 7.7 ; \mathrm{N}, 8.9 \%$. ${ }^{1} \mathrm{H}$ NMR $\left(\mathrm{CD}_{3} \mathrm{COCD}_{3}\right) \delta:-0.21(3 \mathrm{H}, \mathrm{s}, \mathrm{PdMe}), 2.26(6 \mathrm{H}$, s, $\left.\mathrm{NMe}_{2}\right), 2.49\left(6 \mathrm{H}, \mathrm{s}, \mathrm{NMe}_{2}\right), 2.64\left(4 \mathrm{H}, \mathrm{AA}^{\prime} \mathrm{BB}^{\prime}, 2\right.$ $\left.\mathrm{CH}_{2}\right), 6.68\left(1 \mathrm{H}, \mathrm{t}, 2 \times{ }^{3} \mathrm{~J}=7.2 \mathrm{~Hz}, p-\mathrm{Ph}\right), 6.81(2 \mathrm{H}, \mathrm{dd}$, ${ }^{3} J=7.2$ and $\left.7.9 \mathrm{~Hz}, m-\mathrm{Ph}\right), 7.37\left(2 \mathrm{H}, \mathrm{d},{ }^{3} J=7.9 \mathrm{~Hz}\right.$, $o-\mathrm{Ph})$.

\subsection{Preparation of $P d M e P h(b p y)$ (4)}

A yellow solution of $3(1.86 \mathrm{~g}, 5.9 \mathrm{mmol})$ and bpy $(1.65 \mathrm{~g}, 10.6 \mathrm{mmol})$ in $30 \mathrm{ml}$ of benzene was stirred for $1 \mathrm{~h}$ at room temperature. Addition of pentane $(20 \mathrm{ml})$ precipitated the bright yellow product, which was collected on a sintered glass filter and subsequently washed with $3 \times 20 \mathrm{ml}$ of pentane. Yield: $82 \%$. Crystals suitable for X-ray structure determination were obtained from acetone / pentane at $-20^{\circ} \mathrm{C}$. Anal. Found: C, 57.2; $\mathrm{H}, 4.6 ; \mathrm{N}, 7.65 . \mathrm{C}_{17} \mathrm{H}_{16} \mathrm{~N}_{2} \mathrm{Pd}$ calcd. C, 57.6; $\mathrm{H}$, $4.55 ; \mathrm{N}, 7.9 \%$. ${ }^{1} \mathrm{H}$ NMR $\left(\mathrm{CD}_{3} \mathrm{COCD}_{3}\right) \delta: 0.38(3 \mathrm{H}, \mathrm{s}$, 
TABLE 3. Crystal data and details of the structure determination

\begin{tabular}{|c|c|c|c|c|}
\hline $\begin{array}{l}\text { Empirical formula } \\
\text { Formula weight } \\
\text { Crystal system } \\
\text { Space group }\end{array}$ & $\begin{array}{l}\mathrm{C}_{12} \mathrm{H}_{21} \mathrm{IN}_{2} \mathrm{Pd}(\mathbf{1 a}) \\
426.64 \\
\text { tetragonal } \\
\mathrm{P4}_{2} / n\end{array}$ & $\begin{array}{l}\mathrm{C}_{16} \mathrm{H}_{13} \mathrm{IN}_{2} \mathrm{Pd}(2 \mathrm{a}) \\
466.62 \\
\text { monoclinic } \\
P 2_{1} / n\end{array}$ & $\begin{array}{l}\mathrm{C}_{13} \mathrm{H}_{24} \mathrm{~N}_{2} \mathrm{Pd}(3) \\
314.77 \\
\text { monoclinic } \\
\mathrm{C} 2 / \mathrm{c}\end{array}$ & $\begin{array}{l}\mathrm{C}_{17} \mathrm{H}_{16} \mathrm{~N}_{2} \mathrm{Pd}(4) \\
354.75 \\
\text { monoclinic } \\
P 2_{1} / n\end{array}$ \\
\hline$a, b, c[\AA]$ & $19.082(1), 19.082(1), 8.5367(5)$ & $8.886(2), 16.788(4), 10.586(5)$ & $23.3019(16), 8.2587(8), 16.8712(18)$ & $8.570(1), 19.486(1), 9.449(1)$ \\
\hline$\alpha, \beta, \gamma[\mathrm{deg}]$ & $90 ; 90 ; 90$ & $90 ; 106.87(3) ; 90$ & $90 ; 115.70(1) ; 90$ & $90 ; 111.36(1) ; 90$ \\
\hline$V\left[\AA^{3}\right]$ & $3108.4(3)$ & $1511.2(9)$ & $2925.6(5)$ & $1469.6(3)$ \\
\hline$Z$ & 8 & 4 & 8 & 4 \\
\hline$D_{\text {calc }}\left[\mathrm{g} / \mathrm{cm}^{3}\right]$ & 1.823 & 2.051 & 1.429 & 1.603 \\
\hline$F(000)$ [Electrons] & 1648 & 888 & 1296 & 712 \\
\hline$\mu(\mathrm{Mo} \mathrm{K} \alpha)[/ \mathrm{cm}]$ & 31.3 & 32.2 & 12.3 & 12.4 \\
\hline Crystal size [mm] & $0.25 \times 0.25 \times 0.30$ & $0.05 \times 0.05 \times 1.20$ & $0.25 \times 0.33 \times 0.63$ & $0.03 \times 0.40 \times 0.68$ \\
\hline Temperature (K) & 295 & 300 & 300 & 300 \\
\hline Radiation $(\AA)$ & Mo $\mathrm{K} \alpha(\mathrm{Zr}) 0.71073$ & Mo $\mathrm{K} \alpha$ (mon) 0.71073 & $\operatorname{MoK} \alpha$ (mon) 0.71073 & MoK $\alpha($ mon) 0.71073 \\
\hline $\begin{array}{l}\text { Theta min-max } \\
\text { (deg) }\end{array}$ & $1.0 ; 27.5$ & $1.21 ; 27.5$ & $1.34 ; 25.3$ & $0.1 ; 27.5$ \\
\hline Scan type & $\omega / 2 \theta$ & $\omega / 2 \theta$ & $\omega / 2 \theta$ & $\omega / 2 \theta$ \\
\hline Scan, (deg) & $0.55+0.35 \operatorname{tg} \theta$ & $0.74+0.35 \operatorname{tg} \theta$ & $0.73+0.35 \operatorname{tg} \theta$ & $0.74+0.35 \operatorname{tg} \theta$ \\
\hline $\begin{array}{l}\text { Reference } \\
\quad \text { reflection (s) }\end{array}$ & $122 ; 1 \overline{2} \overline{2}$ (no decay) & $421 ; 21 \overline{4} ; 122$ (no decay) & $\overline{2} 0 \overline{6} ; 62 \overline{3} ; 912$ (small decay) & $27 \overline{1} ; 22 \overline{5} ; 202$ (6\% decay) \\
\hline Dataset & $0: 24 ; 0: 24 ;-11: 11$ & $-11: 11 ;-21: 0 ; 0: 13$ & $-26: 0 ;-9: 0 ;-17: 19$ & $-11: 11 ;-25: 0 ;-12: 12$ \\
\hline Tot. uniq. data & $7561 ; 3566$ & $6378 ; 3472$ & $2645 ; 2387$ & $7392 ; 3361$ \\
\hline $\begin{array}{l}\text { Observed data } \\
\qquad[I>2.5 \sigma(I)]\end{array}$ & 2315 & 1999 & 2089 & 2750 \\
\hline$N_{\text {ref }}, N_{\text {par }}$ & 2315,160 & $1999 ; 182$ & $2089 ; 205$ & $2750 ; 245$ \\
\hline$R, R_{w}, S$ & $0.050 ; 0.042 ; 2.56$ & $0.055 ; 0.053 ; 2.36$ & $0.025 ; 0.034 ; 1.64$ & $0.033 ; 0.043 ; 0.71$ \\
\hline $\begin{array}{l}\text { Weighting } \\
\text { scheme, } \mathbf{w}^{-1}\end{array}$ & $\sigma^{2}(\mathrm{~F})$ & $\sigma^{2}(\mathrm{~F})$ & $\sigma^{2}(\mathrm{~F})$ & $\sigma^{2}(\mathrm{~F})+0.0003 \mathrm{~F}^{2}$ \\
\hline $\begin{array}{l}\text { Max. and av. } \\
\text { shift/error }\end{array}$ & $0.3 ; 0.05$ & $0.03 ; 0.006$ & $0.36 ; 0.05$ & $0.4 ; 0.03$ \\
\hline $\begin{array}{l}\text { Min. and max. } \\
\text { resd. dens. } \\
{\left[\mathrm{e} / \AA^{3}\right]}\end{array}$ & $-0.86 ; 0.91$ & $-1.19 ; 0.80$ & $-0.27 ; 0.49$ & $-0.50 ; 1.11$ \\
\hline
\end{tabular}

PdMe), $6.83\left(1 \mathrm{H}, \mathrm{t}, 2 \times{ }^{3} J=7.2 \mathrm{~Hz}, p-\mathrm{Ph}\right), 6.97(2 \mathrm{H}$, dd, ${ }^{3} J=7.2$ and $\left.7.9 \mathrm{~Hz}, m-\mathrm{Ph}\right), 7.48\left(2 \mathrm{H}, \mathrm{d},{ }^{3} J=7.9\right.$ $\mathrm{Hz}$, o-Ph), 7.52 (1H, m, $\mathbf{H}_{5}$-bpy), 7.74 (1H, m, $\mathrm{H}_{5}$-bpy), 8.20 ( $3 \mathrm{H}, \mathrm{m}, \mathrm{H}_{6^{\prime}}$ and $\mathrm{H}_{4,4^{\prime}}$-bpy), 8.49 ( $2 \mathrm{H}, \mathrm{m}, \mathrm{H}_{3,3^{\prime}}$-bpy), $8.80\left(1 \mathrm{H}, \mathrm{d},{ }^{3} \mathrm{~J}=5.2 \mathrm{~Hz}, \mathrm{H}_{6}\right.$-bpy).

\section{7. $X$-ray structural analyses}

Gcneral: Scattering factors were taken from Cromer and Mann and corrected for anomalous dispersion [27]. All calculations were carried out on a DEC 5000 system. Geometrical calculations and illustrations were done with PLATON [28]. Crystal data and details of the structure determinations are presented in Table 3 . Fractional atomic coordinates are given in Tables 4-7.

\subsubsection{PdIPh(tmeda) (1a) [9a]}

For a yellow crystal glued on top of a glass fibre, a total of 7561 reflections were scanned on an EnrafNonius CAD4 diffractometer. Unit cell parameters were derived from the 25 SET4 setting angles in the range $12^{\circ}<\theta<20^{\circ}$. Data were corrected for $L p$ and absorption (DIFABs [29]). The structure was solved by Patterson techniques (sHELXs86 [30]) and refined by full matrix least squares on $F$ (sHELX76 [31]) to a final
$R=0.050$. Hydrogen atoms were refined, riding on their carrier atoms, with three common isotropic thermal parameters.

TABLE 4. Fractional coordinates and equivalent isotropic thermal parameters for PdIPh(tmeda) (1a)

\begin{tabular}{lllll}
\hline & $x$ & $y$ & $z$ & $U_{\mathrm{eq}}\left(\AA^{2}\right)^{\mathrm{a}}$ \\
\hline $\mathrm{I}$ & $0.20966(3)$ & $0.55604(3)$ & $0.55597(7)$ & $0.0835(2)$ \\
$\mathrm{Pd}$ & $0.28117(3)$ & $0.50921(3)$ & $0.32328(6)$ & $0.0534(2)$ \\
$\mathrm{N}(1)$ & $0.3377(3)$ & $0.4685(3)$ & $0.1288(7)$ & $0.064(2)$ \\
$\mathrm{N}(2)$ & $0.2342(3)$ & $0.5788(3)$ & $0.1479(7)$ & $0.067(2)$ \\
$\mathrm{C}(1)$ & $0.3035(5)$ & $0.4967(6)$ & $-0.010(1)$ & $0.108(4)$ \\
$\mathrm{C}(2)$ & $0.2799(6)$ & $0.5686(5)$ & $0.008(1)$ & $0.106(5)$ \\
$\mathrm{C}(3)$ & $0.3356(6)$ & $0.3921(4)$ & $0.117(1)$ & $0.113(5)$ \\
$\mathrm{C}(4)$ & $0.4125(4)$ & $0.4901(5)$ & $0.132(1)$ & $0.098(4)$ \\
$\mathrm{C}(5)$ & $0.2383(5)$ & $0.6535(4)$ & $0.188(1)$ & $0.093(4)$ \\
$\mathrm{C}(6)$ & $0.1606(5)$ & $0.5607(6)$ & $0.121(1)$ & $0.120(5)$ \\
$\mathrm{C}(7)$ & $0.3269(4)$ & $0.4435(4)$ & $0.4731(8)$ & $0.061(3)$ \\
$\mathrm{C}(8)$ & $0.3889(4)$ & $0.4599(4)$ & $0.5477(9)$ & $0.075(3)$ \\
$\mathrm{C}(9)$ & $0.4216(5)$ & $0.4147(6)$ & $0.647(1)$ & $0.086(4)$ \\
$\mathrm{C}(10)$ & $0.3919(6)$ & $0.3504(6)$ & $0.680(1)$ & $0.092(4)$ \\
$\mathrm{C}(11)$ & $0.3301(5)$ & $0.3328(5)$ & $0.611(1)$ & $0.085(4)$ \\
$\mathrm{C}(12)$ & $0.2975(4)$ & $0.3799(4)$ & $0.5064(9)$ & $0.075(3)$ \\
\hline
\end{tabular}

${ }^{\text {a }} U_{\text {eq }}=1 / 3$ trace of the orthogonalized $U$ tensor. 
TABLE 5. Final coordinates and equivalent isotropic thermal parameters for $\mathrm{PdIPh}(\mathrm{bpy})$ (2a)

\begin{tabular}{|c|c|c|c|c|}
\hline & $x$ & $y$ & $z$ & $U_{\text {eq }}\left(\AA^{2}\right)^{a}$ \\
\hline I & $0.25343(10)$ & $0.14349(5)$ & $0.67802(7)$ & $0.0671(3)$ \\
\hline Pd & $0.20710(10)$ & $0.12830(4)$ & $0.90592(8)$ & $0.0474(3)$ \\
\hline $\mathbf{N}(1)$ & $0.1485(10)$ & $0.1092(5)$ & $1.0790(8)$ & $0.051(3)$ \\
\hline$N(2)$ & $0.2693(10)$ & $0.0056(5)$ & $0.9453(9)$ & $0.050(3)$ \\
\hline$C(2)$ & $0.1605(13)$ & $0.2446(6)$ & $0.9032(10)$ & $0.052(3)$ \\
\hline$C(3)$ & $0.2857(14)$ & $0.2949(6)$ & $0.9653(12)$ & $0.060(4)$ \\
\hline$C(4)$ & $0.2583(17)$ & $0.3743(7)$ & $0.9835(12)$ & $0.074(5)$ \\
\hline$C(5)$ & $0.1125(18)$ & $0.4057(7)$ & $0.9444(14)$ & $0.079(6)$ \\
\hline$C(6)$ & $-0.0114(17)$ & $0.3555(9)$ & $0.8827(15)$ & $0.087(6)$ \\
\hline$C(7)$ & $0.0128(14)$ & $0.2752(7)$ & $0.8593(12)$ & $0.066(4)$ \\
\hline$C(8)$ & $0.0823(13)$ & $0.1628(7)$ & $1.1407(11)$ & $0.058(4)$ \\
\hline$C(9)$ & $0.0330(13)$ & $0.1426(7)$ & $1.2484(11)$ & $0.061(4)$ \\
\hline$C(10)$ & $0.0547(14)$ & $0.0658(8)$ & $1.2965(12)$ & $0.067(4)$ \\
\hline$C(11)$ & $0.1216(13)$ & $0.0119(7)$ & $1.2323(11)$ & $0.060(4)$ \\
\hline $\mathrm{C}(12)$ & $0.1722(12)$ & $0.0336(6)$ & $1.1284(10)$ & $0.048(3)$ \\
\hline$C(13)$ & $0.2440(12)$ & $-0.0228(6)$ & $1.0531(11)$ & $0.050(3)$ \\
\hline$C(14)$ & $0.2860(15)$ & $-0.0982(6)$ & $1.0976(13)$ & $0.066(4)$ \\
\hline$C(15)$ & $0.3525(15)$ & $-0.1488(7)$ & $1.0227(13)$ & $0.075(5)$ \\
\hline$C(16)$ & $0.3752(15)$ & $-0.1183(7)$ & $0.9103(13)$ & $0.074(5)$ \\
\hline$C(17)$ & $0.3329(13)$ & $-0.0422(6)$ & $0.8710(12)$ & $0.058(4)$ \\
\hline
\end{tabular}

${ }^{\mathrm{a}} U_{\mathrm{eq}}=1 / 3$ trace of the orthogonalized $U$ tensor.

\subsection{2. $P d I P h(b p y)(2 a)$}

Data were collected on an Enraf-Nonius CAD4T/ rotating anode system from an orange, needle-shaped crystal glued on top of a glass fibre. Cell parameters were derived from the setting angles of 25 reflections (SET4) in the range $9^{\circ}<\theta<14^{\circ}$. A total of 6378 reflections was scanned, corrected for $L p$ and absorption / extinction (DIFABs [29]) and merged $\left(R_{\text {int }}=0.052\right)$ into a unique set of 1999 reflections with $I>2.5 \sigma(I)$. The structure was solved by direct methods (SHELXS86

TABLE 6. Fractional coordinates and equivalent isotropic thermal parameters for PdMePh(tmeda) (3)

\begin{tabular}{llccl}
\hline & $x$ & $y$ & $z$ & $U_{\text {eq }}\left(\AA^{2}\right)^{a}$ \\
\hline Pd & $0.13299(1)$ & $0.12710(3)$ & $0.12574(1)$ & $0.0398(1)$ \\
$\mathrm{N}(1)$ & $0.14366(15)$ & $-0.0465(4)$ & $0.22975(18)$ & $0.0563(10)$ \\
$\mathrm{N}(2)$ & $0.13015(15)$ & $-0.0965(3)$ & $0.05213(19)$ & $0.0499(9)$ \\
$\mathrm{C}(1)$ & $0.13683(19)$ & $0.3307(4)$ & $0.2031(2)$ & $0.0483(11)$ \\
$\mathrm{C}(2)$ & $0.11831(15)$ & $0.2768(3)$ & $0.0267(2)$ & $0.0414(10)$ \\
$\mathrm{C}(3)$ & $0.16352(18)$ & $0.3137(5)$ & $-0.0040(2)$ & $0.0499(11)$ \\
$\mathrm{C}(4)$ & $0.1490(2)$ & $0.4061(5)$ & $-0.0779(3)$ & $0.0609(14)$ \\
$\mathrm{C}(5)$ & $0.0898(2)$ & $0.4651(5)$ & $-0.1246(3)$ & $0.0689(16)$ \\
$\mathrm{C}(6)$ & $0.0442(2)$ & $0.4367(5)$ & $-0.0960(3)$ & $0.0662(14)$ \\
$\mathrm{C}(7)$ & $0.05857(17)$ & $0.3482(4)$ & $-0.0213(2)$ & $0.0538(12)$ \\
$\mathrm{C}(8)$ & $0.1593(2)$ & $-0.2041(4)$ & $0.2000(3)$ & $0.0690(4)$ \\
$\mathrm{C}(9)$ & $0.1206(2)$ & $-0.2281(4)$ & $0.1030(3)$ & $0.0669(14)$ \\
$\mathrm{C}(10)$ & $0.1895(3)$ & $-0.1188(6)$ & $0.0439(4)$ & $0.0762(19)$ \\
$\mathrm{C}(11)$ & $0.0771(3)$ & $-0.0978(6)$ & $-0.0365(3)$ & $0.0700(14)$ \\
$\mathrm{C}(12)$ & $0.0825(3)$ & $-0.0576(8)$ & $0.2364(4)$ & $0.085(2)$ \\
$\mathrm{C}(13)$ & $0.1955(3)$ & $-0.0110(7)$ & $0.3171(3)$ & $0.0852(18)$ \\
\hline
\end{tabular}

${ }^{\mathrm{a}} U_{\mathrm{cy}}=1 / 3$ trace of the orthogonalized $U$ tensor.
TABLE 7. Fractional coordinates and equivalent isotropic thermal parameters for PdMePh(bpy) (4)

\begin{tabular}{llcll}
\hline & $x$ & $y$ & $z$ & $U_{\mathrm{eq}}\left(\AA^{2}\right)^{\mathrm{a}}$ \\
\hline $\mathrm{Pd}$ & $0.74577(3)$ & $-0.08695(1)$ & $0.84386(3)$ & $0.0511(1)$ \\
$\mathrm{N}(1)$ & $0.8141(3)$ & $0.00975(13)$ & $0.7822(3)$ & $0.0541(8)$ \\
$\mathrm{N}(2)$ & $0.7390(3)$ & $-0.02165(14)$ & $1.0233(3)$ & $0.0563(8)$ \\
$\mathrm{C}(1)$ & $0.8623(5)$ & $0.0219(2)$ & $0.6645(4)$ & $0.0666(12)$ \\
$\mathrm{C}(2)$ & $0.9119(6)$ & $0.0849(2)$ & $0.6344(6)$ & $0.0773(17)$ \\
$\mathrm{C}(3)$ & $0.9123(6)$ & $0.1382(2)$ & $0.7262(6)$ & $0.0844(16)$ \\
$\mathrm{C}(4)$ & $0.8652(5)$ & $0.12760(18)$ & $0.8493(6)$ & $0.0757(14)$ \\
$\mathrm{C}(5)$ & $0.8161(4)$ & $0.06212(17)$ & $0.8751(4)$ & $0.0569(9)$ \\
$\mathrm{C}(6)$ & $0.7645(4)$ & $0.04567(17)$ & $1.0035(4)$ & $0.0569(10)$ \\
$\mathrm{C}(7)$ & $0.7399(5)$ & $0.0946(2)$ & $1.1003(6)$ & $0.0743(12)$ \\
$\mathrm{C}(8)$ & $0.6887(6)$ & $0.0751(3)$ & $1.2156(5)$ & $0.0834(17)$ \\
$\mathrm{C}(9)$ & $0.6657(5)$ & $0.0079(3)$ & $1.2356(5)$ & $0.0793(16)$ \\
$\mathrm{C}(10)$ & $0.6917(5)$ & $-0.0395(2)$ & $1.1388(4)$ & $0.0679(11)$ \\
$\mathrm{C}(11)$ & $0.7373(4)$ & $-0.13926(16)$ & $0.6610(3)$ & $0.0535(9)$ \\
$\mathrm{C}(12)$ & $0.8676(5)$ & $-0.1807(2)$ & $0.6568(5)$ & $0.0659(11)$ \\
$\mathrm{C}(13)$ & $0.8672(5)$ & $-0.2123(2)$ & $0.5277(5)$ & $0.0720(14)$ \\
$\mathrm{C}(14)$ & $0.7330(6)$ & $-0.2054(2)$ & $0.3953(5)$ & $0.0706(14)$ \\
$\mathrm{C}(15)$ & $0.6012(6)$ & $-0.1667(3)$ & $0.3946(5)$ & $0.0856(16)$ \\
$\mathrm{C}(16)$ & $0.6038(5)$ & $-0.1338(2)$ & $0.5251(4)$ & $0.0777(14)$ \\
$\mathrm{C}(17)$ & $0.6901(8)$ & $-0.1771(2)$ & $0.9200(7)$ & $0.0819(18)$ \\
\hline
\end{tabular}

${ }^{\mathrm{a}} U_{\text {eq }}=1 / 3$ trace of the orthogonalized $U$ tensor.

[30]) and refined by full matrix least-squares on $F$ (SHELX76 [31]) to a final $R=0.055$. Hydrogen atoms were taken into account at calculated positions with one common $U_{\text {iso }}$.

\subsubsection{PdMePh (tmeda) (3)}

A transparent, block shaped crystal was mounted on top of a glass fibre and transferred to an Enraf-Nonius CAD4T/rotating anode diffractometer. Precise lattice parameters and their standard deviations were derived from the angular setting of 25 reflections in the range $11^{\circ}<\theta<16^{\circ}$. The net intensities of the data were corrected for Lorentz and polarization effects and a small linear decay. An absorption correction was applied using standard Patterson methods (sHELXs86 [30]) and subsequent difference Fourier syntheses, and refined by full-matrix least-squares techniques on $F$ (sHELX76 [31]). All hydrogen atoms were introduced on calculated positions ( $\mathrm{C}-\mathrm{H}=0.98 \AA$ ) and included in the refinement riding on their carrier atoms. All nonhydrogen atoms were refined with anisotropic thermal parameters. An empirical isotropic extinction coefficient (final value $=0.00019(2)$ ) was refined. Refinement converged at $R=0.0249\left(R_{w}=0.0339\right)$.

\subsection{4. $P d M e P h(b p y)(4)[9 b]$}

A yellow crystal was glued on top of a glass fibre and transferred for data collection to an Enraf-Nonius CAD4T/rotating anode system. Unit cell parameters were derived from the 25 SET4 setting angles in the 
range $11^{\circ}<\theta<14^{\circ}$. A redundant set of 7392 reflections was scanned, corrected for $L p$, and merged into a unique set of 2750 reflections with $I>2.5 \sigma(I)$. The structure was solved with the PATT option of SHELXS86 [30] and refined with SHELX76 [31] by full-matrix leastsquares techniques. Convergence was reached at $R=$ 0.033 . Hydrogen atoms were located from a difference density map, and their positions and isotropic thermal parameters refined.

Additional material available from the Cambridge Crystallographic Data Centre comprises $\mathrm{H}$-atom coordinates, thermal parameters and a complete list of bond lengths and angles.

\section{Acknowledgments}

This work was supported in part (W.J.J.S. and A.L.S.) by the Netherlands Foundation for Chemical Research (SON) with financial aid from the Netherlands Organization for Scientific Research (NWO). Financial support for a visit by A.J.C. to Utrecht from NWO, Utrecht University, the University of Tasmania, the Ian Potter Foundation (Australia), and the Department of Industry, Trade, and Commerce (Australia) is gratefully acknowledged.

\section{References}

1 For recent reviews see: (a) A.D. Ryabov, Synthesis, (1985) 233; (b) M. Pfeffer, Recl. Trav. Chim. Pays-Bas, 109 (1990) 567; (c) M. Pfeffer, Pure Appl. Chem., 64 (1992), 335.

2 (a) R. Sustmann, J. Lau and M. Zipp, Tetrahedron Lett., 27 (1986) 5207; (b) M.E. Wright and C.K. Lowe-Ma, Organometallics, 9 (1990) 347; (c) R. van Asselt and C.J. Elsevier, Organometallics, 11 (1992) 1999; (d) J.M. Brown, M. Pearson, J.T.B.H. Jastrzebski and G. van Koten, J. Chem. Soc., Chem. Commun., (1992) 1440.

3 (a) M. Catellani and G.P. Chiusoli, J. Organomet. Chem., 346 (1988) C27; (b) M. Catellani and B.E. Mann, J. Organomet. Chem., 390 (1990) 251; (c) M. Catellani and G.P. Chiusoli, J. Organomet. Chem., 425 (1992) 151; (d) B.A. Markies, P. Wijkens, H. Kooijman, A.L. Spek, J. Boersma and G. van Koten, J. Chem. Soc., Chem. Commun., (1992) 1420; (e) G. Bocelli, M. Catellani and S. Ghelli, J. Organomet. Chem., 458 (1993) $\mathrm{C} 12$.

4 (a) M.D. Rausch and F.E. Tibbetts, J. Organomet. Chem., 21 (1970) 487; (b) R. Uson, J. Fornies and R. Navarro, J. Organomet. Chem., 96 (1975) 307; (c) R. Uson, J. Fornies and R. Navarro, Syn. React. Inorg. Metal.-Org. Chem., 7 (1977) 235; (d) R. Uson and J. Fornies, Adv. in Organomet. Chem., 28 (1988) 219 and references therein; (e) R. Uson, J. Fornies and M. Tomas, J. Organomet. Chem., 358 (1988) 525 and references therein.

5 (a) A.J. Canty, Acc. Chem. Res., 25 (1992) 83 and references therein; (b) A.J. Canty, P.R. Traill, B.W. Skelton and A.H. White, J. Organomet. Chem., 433 (1992) 213; (c) P.K. Byers, A.J. Canty, R.T. Honeyman, B.W. Skelton and A.H. White, J. Organomet. Chem., 433 (1992) 223; (d) A.J. Canty and P.R. Traill, J. Organomet. Chem., 435 (1992) C8; (e) P.K. Byers, A.J. Canty,
B.W. Skelton, P.R. Traill, A.A. Watson and A.H. White, Organometallics, 11 (1992) 3085; (f) A.J. Canty, Platinum Metals Rev., 37 (1993) 2; (g) M.A. Bennett, A.J. Canty, J.K. Felixberger, L.M. Rendina, C. Sunderland and A.C. Willis, Inorg. Chem., 32 (1993) 1951.

6 (a) W. de Graaf, J. Boersma, W.J.J. Smeets, A.L. Spek and G. van Koten, Organometallics, 8 (1989) 2907; (b) W. de Graaf, J. Boersma and G. van Koten, Organometallics, 9 (1990) 1479; (c) P.L. Alsters, P.F. Engel, M.P. Hogerheide, M. Copijn, A.L. Spek and G. van Koten, Organometallics, 12 (1993) 1831.

7 A.V. Kavaliunas, A. Taylor and R.D. Rieke, Organometallics, 2 (1983) 377.

8 V.I. Sokolov, V.V. Bashilov and O.A. Reutov, J. Organomet. Chem., 97 (1975) 299.

9 For preliminary reports see: (a) W. de Graaf, J. van Wegen, J. Boersma, A.L. Spek and G. van Koten, Recl. Trav. Chim. PaysBas, 108 (1989) 275; (b) B.A. Markies, A.J. Canty, M.D. Janssen, A.L. Spek, J. Boersma and G. van Koten, Recl. Trav. Chim. Pays-Bas, 110 (1991) 477.

10 Y. Fuchita, M. Kawakami and K. Shimoke, Polyhedron, 10 (1991) 2037.

11 Sce, for example (a) J.K. Stille and K.S.Y. Lau, Acc. Chem. Res. 10 (1977) 434; (b) J.K. Stille, in F.R. Hartley and S. Patai, (eds) The Chemistry of the Metal-Carbon Bond, Wiley, New York, 1985; (c) C. Amatore and F. Pflüger, Organometallics, 9 (1990) 2276; (d) C. Amatore, M. Azzabi and A. Jutand, J. Am. Chem. Soc., 113 (1991) 8375; (e) C. Amatore, A. Jutand and A. Suarez, J. Am. Chem. Soc., 115 (1993) 9531.

12 A.J. Canty, N.J. Minchin, L.M. Engelhardt, B.W. Skelton and A.H. White, Aust. J. Chem., 41 (1988) 651.

13 P.K. Byers and A.J. Canty, Organometallics, 9 (1990) 210.

14 (a) R. McCrindle and A.J. McAlees, J. Chem. Soc., Dalton Trans., (1983) 127; (b) R. McCrindle, D.K. Stephenson, A.J. McAlees and J.M. Willson, J. Chem. Soc., Dalton Trans., (1986) 641.

15 (a) P.L. Alsters, P.J. Baesjou, M.D. Janssen, H. Kooijman, A. Sicherer-Roetman, A.L. Spek and G. van Koten, Organometallics, 11 (1992) 4124; (b) P.L. Alsters, J. Boersma and G. van Koten, Organometallics, 12 (1993) 1629; (c) P.L. Alsters, J. Boersma, W.J.J. Smeets, A.J. Spek and G. van Koten, Organometallics, 12 (1993) 1639; (d) J.M. Valk, Selective Metal-Mediated Oxidation of Naphthalenes, PhD Thesis, Utrecht, 1993.

16 (a) A. Bontempi, E. Alessio, G. Chanos and G. Mestroni, J. Mol. Catal., 42 (1987) 67; (b) M.N. Vargaftik, V.P. Zagorodnikov, I.P. Stolarov, I.I. Moiseev, D.I. Kochubey, V.A. Likholobov, A.L. Chuvilin and K.I. Zamaraev, J. Mol. Catal., 53 (1989) 315; (c) E. Drent, Pure Appl. Chem., 62 (1990) 661; (d) P. Leconte, F. Metz, A. Mortreux, J.A. Osborn, F. Paul, F. Petit and A. Pillot, $J$. Chem. Soc., Chem. Commun. (1990) 1616; (e) Y. Fujiwara, T. Jintoku and K. Takaki, Chemtech, (1990) 636; (f) T. Jintoku, Y. Fujiwara, I. Kawata, T. Kawauchi and H. Taniguichi, J. Organomet. Chem., 385 (1990) 297; (g) R. van Asselt and C.J. Elsevier, J. Mol. Catal., 65 (1991) L13; (h) Z. Zhuangyu, P. Yi, H. Honwen and K. Tsi-yu, Synthesis, (1991) 539; (i) M. Barsacchi, G. Consiglio, L. Medici, G. Petrucci and U.W. Suter, Angew. Chem., Int. Ed. Engl., 30 (1991) 989; (j) A. Batistini, G. Consiglio and U.W. Suter, Angew. Chem., Int. Ed. Engl., 31 (1992) 303; (k) C. Pisano, S.C.A. Nefkens and G. Consiglio, Organometallics, 11 (1992) 1975.

17 (a) G. Calvin and G.E. Coates, J. Chem. Soc., (1960) 2008; (b) H. Reinheimer, J. Moffat and P.M. Maitlis, J. Am. Chem. Soc., 92 (1970) 2285; (c) S. Hasegawa, K. Itoh and Y. Ishii, Inorg. Chem., 13 (1974) 2675; (d) K. Moseley and P.M. Maitlis, J. Chem. Soc., Dalton Trans, (1974) 169; (e) T.S. Ito, S. Hasegawa, Y. Takahashi and Y. Ishii, J. Organomet. Chem., 73 (1974) 401; (f) E.A. Kelly, 
P.M. Bailey and P.M. Maitlis, J. Chem. Soc, Chem. Commun., (1977) 289; (g) R. Pietropaolo, F. Cusmano, E. Rotondo and A. Spadaro, J. Organomet. Chem., 155 (1978) 117; (h) E.A. Kelley and P.M. Maitlis, J. Chem. Soc., Dalton Trans., (1979) 167; (i) M. Bochmann, G. Wilkinson and G.B. Young, J. Chem. Soc., Dalton Trans., (1980) 1879; (j) P. Diversi, G. Ingrosso, A. Lucherini and S. Murtas, J. Chem. Soc., Dalton Trans., (1980) 1633; (k) P. Diversi, G. Ingrosso and A. Lucherini, Inorg. Synth., 22 (1983) 167; (l) P. Diversi, D. Fasce and R. Santini, J. Organomet. Chem., 269 (1984) 285; (m) R. Sustmann and J. Lau, Chem. Ber., 119 (1986) 2531 ; (n) C. Cornioley-Deuschel and A. von Zelewsky, Inorg. Chem., 26 (1987) 3354; (o) P. Diversi, G. Ingrosso, A Lucherini, T. Lumini, F. Marchetti, V. Adovasio and M. Nardelli, J. Chem. Soc. Dalton Trans., (1988) 133; (p) P.K. Byers, A.J. Canty, B.W. Skelton and A.H. White, J. Organomet. Chem., 393 (1990) 299.

18 (a) H. Nakazawa, F. Ozawa and A. Yamamoto, Organometallics, 2 (1983) 241; (b) F. Ozawa, M. Fujimori, T. Yamamoto and A. Yamamoto, Organometallics, 5 (1986) 2144; (c) F. Ozawa, K. Kurihara, M. Fujimori, T. Hidaka, T. Toyoshima and A. Yamamoto, Organometallics, 8 (1989) 180.

19 A.D. Ryabov, G.M. Kazankov, A.K. Yatsimirsky, L.G. Kuz'mina, O.Y. Burtseva, N.V. Dvortsova and V.A. Polyakov, Inorg. Chem., 31 (1992) 3083.

20 A.L. Seligson and W.C. Trogler, J. Am. Chem. Soc., 113 (1991) 2520.

21 (a) B.A. Markies, M.H.P. Rietveld, J. Boersma, A.L. Spek and G. van Koten, J. Organomet. Chem., 424 (1992) C12; (b) B.A. Markies, D. Kruis, M.H.P. Rietveld, K.A.N. Verkerk, J. Boersma,
H. Kooijman, M.T. I akin, A.I. Spek and G. van Koten, J. Am Chem. Soc., to be submitted.

22 (a) R.E. Rülke, I.M. Han, C.J. Elsevier, K. Vrieze, P.W.N.M. van Leeuwen, C.F. Roobeek, M.C. Zoutberg, Y.F. Wang and C.H. Stam, Inorg. Chim. Acta, 169 (1990) 5; (b) G.P.C.M. Dekker, C.J. Elsevier, K. Vrieze and P.W.N.M. van Leeuwen, Organometallics, 11 (1992) 1598; (c) G.P.C.M. Dekker, A. Buijs, C.J. Elsevier, K. Vrieze, P.W.N.M. van Leeuwen, W.J.J. Smeets, A.L. Spek, Y.F. Wang and C.H. Stam, Organometallics, 11 (1992) 1937; (d) R.E. Rülke, J.M. Ernsting, A.L. Spek, C.J. Elsevier, P.W.N.M. van Leeuwen and K. Vrieze, Inorg. Chem., 32 (1993) 5769.

23 (a) P.K. Byers, A.J. Canty, L.M. Engelhardt and A.H. White, $J$. Chem. Soc., Dalton Trans., (1986) 1731; (b) P.K. Byers, A.J. Canty and R.T. Honeyman, J. Organomet. Chem., 385 (1990) 417.

24 V.G. Albano, C. Castellari, M.E. Cucciolito, A. Panunzi and A. Vitagliano, Organometallics, 9 (1990) 1269.

25 B.A. Markies, A.J. Canty, J. Boersma and G. van Koten, Organometallics, 13 (1994) 2053.

26 M.F. Rettig, P.M. Maitlis, F.A. Cotton and T.R. Webbs, Inorg. Synth., (1971) 134.

27 (a) D.T. Cromer and J.B. Mann, Acta Crystallogr. A24 (1968) 321; (b) D.T. Cromer and D. Liberman, J. Chem. Phys., 53 (1970) 1891.

28 A.L. Spek, Acta Crystallogr. A46 (1990) C34.

29 N. Walker and D. Stuart, Acta Crystallogr. A39 (1983) 158.

30 G.M. Sheldrick, sHELXs86. Program for crystal structure determination, University of Göttingen, Germany, 1986.

31 G.M. Sheldrick, sHELX76. Crystal structure analysis package, University of Cambridge, UK, 1976. 